\title{
Coronary artery bypass surgery in patients with low ejection fraction: short and mid term outcomes according to the associated risk factors
}

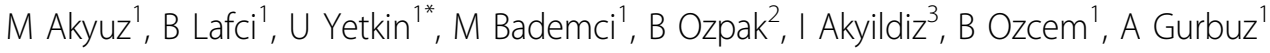 \\ From 23rd World Congress of the World Society of Cardio-Thoracic Surgeons \\ Split, Croatia. 12-15 September 2013
}

\section{Background}

Left ventricular dysfunction increases the rate of mortality and morbidity after coronary artery bypass grafting (CABG).

\section{Methods}

Thirty seven consecutive patients with low ejection fraction (EF) who underwent CABG in our department were analysed retrospectively ( 8 women and 29 men, mean age $62,32 \pm 10,86$ years, range 40 to 78 years). Eight patients underwent off-pump bypass.

\section{Results}

Twenty-two patients were diabetic (\%59.5), 24 patients had hypertension (64.9\%), 14 patients had hyperlipidemia (\%37.8), 27 patients had a history of smoking (\%73), two patients had chronic obstructive pulmonary disease (\%5.4), six patients had peripheral artery disease (\%16.2), one patient had a history of cerebrovascular accident (\%2.7), one patient had a history of intracardiac defibrillator implantation (\%2.7), three patients had percutaneous coronary intervention (\%8.1).

\section{Conclusion}

Risk factors should be evaluated for the short and midterm outcomes of patients with low EF undergoing CABG.

\section{Authors' details}

'Izmir Katip Celebi University Ataturk Training and Research Hospital, Department of Cardiovascular Surgery, Izmir, Turkey. ${ }^{2}$ Tekirdag State Hospital Dept. of Cardiovascular Surgery, Tekirdag, Turkey. ${ }^{3}$ Izmir Katip Celebi

\footnotetext{
* Correspondence: ufuk_yetkin@yahoo.fr

'Izmir Katip Celebi University Ataturk Training and Research Hospital,

Department of Cardiovascular Surgery, Izmir, Turkey

Full list of author information is available at the end of the article
}

University Ataturk Training and Research Hospital, Department of Cardiology, Izmir, Turkey.

Published: 11 September 2013

doi:10.1186/1749-8090-8-S1-P99

Cite this article as: Akyuz et al:: Coronary artery bypass surgery in patients with low ejection fraction: short and mid term outcomes according to the associated risk factors. Journal of Cardiothoracic Surgery 2013 8(Suppl 1):P99.
Submit your next manuscript to BioMed Central and take full advantage of:

- Convenient online submission

- Thorough peer review

- No space constraints or color figure charges

- Immediate publication on acceptance

- Inclusion in PubMed, CAS, Scopus and Google Scholar

- Research which is freely available for redistribution

Submit your manuscript at www.biomedcentral.com/submit
C Bïomed Central 